\title{
The Advantages of Green Management for Hotel Competitiveness in Taiwan: In the Viewpoint of Senior Hotel Managers
}

\author{
Ying-Chang Chen $^{1} \&$ Yu-Ta Chen ${ }^{2}$ \\ ${ }^{1}$ Department of Hotel and Restaurant Management, Ching Kuo Institute of Management and Health, Keelung \\ City, Taiwan (R.O.C.) \\ ${ }^{2}$ Department of International Business, Kainan University, Taoyuan, Taiwan (R.O.C.) \\ Correspondence: Ying-Chang Chen, Department of Hotel and Restaurant Management, Ching Kuo Institute of \\ Management and Health, No.336 Fu-Hsing Rd., Keelung City 20301, Taiwan (R.O.C.). Tel: 886-2-2437-2093. \\ E-mail: proteus@ems.cku.edu.tw
}

Received: January 4, 2012 Accepted: April 24, 2012 Online Published: July 5, 2012

doi:10.5539/jms.v2n2p211 URL: http://dx.doi.org/10.5539/jms.v2n2p211

\begin{abstract}
The purpose of this study is to investigate the advantages of green management for hotel competiveness based on the viewpoint of hotel senior managers. Case study and in-depth interview are used as our study method. The finding of this study is that the two hotels from our case study have successfully reduced their operation cost as well as entire society cost after implementing green management. The hotels also gained intangible assets and brand effect such as reputation and brand effects with green management. Through the interviews with hotel senior managers, we learned that hotels can achieve the standard of green business through self-examining 5 keys, namely green purchase, environmental policy, management system, employee education, and consumer education respectively. It can also strengthen hotels' key competiveness in the aspect of environmental protection and health as well as highlight hotels' features. The findings of this study can provide useful information for other green hotels.
\end{abstract}

Keywords: senior manager, green management, green hotel, in-depth interview

\section{Background and Motives}

Pollution is increasingly produced by energy over-consumption these recent years, which caused many environmental problems. The speed of energy consumption is far beyond that of restoration. Therefore, the concept of environmental management and energy sustainable utilization has been suggested more often than never before. Environmental protection is a major task that we need to take action upon. On the contrary, environmental pollution and its negative impacts are brought about while people are focusing on economic growth and tourism development. Hotel industry is one of the major parts in tourism development, so it consumes considerable amount of resource and energy on earth. If green management can be effectively implemented, not only can cost-effective, but also the negative environmental impacts can be reduced.

Hotel industry worldwide is currently getting more and more concerned about environmental issues. Bohdanowicz and Martinac (2007) indicated that $75 \%$ of environmental pollution caused by hotel industry was from over-consuming energy, water, and materials while operating business. The waste water, fume, and materials discharged during the operation would cause negative impacts on our environment. Thus, without proper design and plan, environment would be impacted in an unwanted way. The concept of environment protection and energy saving can induce green management into hotel facility construction. If hotel industry can put the idea of green management into practice, not only can it benefit environmental and ecological protection, but it would also reduce hotel operation cost. Moreover, green marketing can attract consumers who are in favor of the same idea as well.

For example, the heating system of Far Eastern Plaza hotel, a firm that adopted the idea of green hotel in the early stage, uses air-exchange in winter, which can save averagely 300 tons of oil equivalent electricity every day. In summer, they use ice-storage air conditioning system, which produces 1,500 tons of ice cubes at night, so the melting ice can provide cold air for air-conditioning system. Not only can the system save 2.5 million dollars on electricity bill, but it also reduces electricity load in the peak hours. In addition, the discharged waste water from 
the swimming poor (temperature of 43F) is collected and re-processed and used for the cooling tower. The purpose of these drills is to fully take advantage of energy. Far Eastern Plaza Hotel has been expanding rapidly these recent years; therefore, the energy demand is relatively increased. However, the electricity consumption is only $181 \mathrm{kWh}$ per square meter every year, Compared to the average energy needs of $262 \mathrm{kWh}$ of other tourist hotels, the system is excellent for energy saving. The effort of energy saving is also rewarded by the Ministry of Economics Affair.

This study is exploring the advantages of green management on hotel competitiveness from the viewpoint of senior managers through two case studies. In addition, we will provide management suggestions to other hotels for reference based on 5 major aspects.

\section{Literature Review}

\subsection{Definition of Green Hotel}

Global economics is growing rapidly with the last decades and thus enhancing our living quality. On the contrary, environmental protection issue started to concern people. In order to reach a higher level of living condition, we need to start protecting our environment. Founded in 1993, Green Hotel Association aims to increase hotels' interests in environmental issue (Kong Fang Zheng et al., 2001), followed by Green Seal in the United States, Environmental Choice in Canada, and Green Management in Practice (GMIP) in Norway. Tourism Council Australia (1998) proposed that the idea of green hotel is to provide natural accommodation and facility including green services, green products, and fresh and comfortable environment. Lee Ni (2002) also suggested that a green hotel is a hotel which provides both facilities and services with the idea of environmental protection. For example, when building a new hotel, try to use recycled construction material without compromising safety. According to the definition from Green Purchasing Network, green hotel should include hotel, inn, Pension, YMCA, Villa, and motel (Liao,Tzu-Hsuan and Su, Wen-Yu, 2007). The idea of environmental protection should be introduced into facilities and products, so our environment would not be harmed. Green Mountain State (2006) defined a green hotel as "a hotel that makes efforts on creating a fine environment and encourages its staff and customers to participate in the activity. It also needs to observe carefully each operation to reduce impacts on environment". Green Hotels Association defined a green hotel as "a hotel which saves water and energy in a constructive manner and reduces solid wastes to maintain our environment" (Judy et al, 2007). In Erdogan and Baris' study (2007), it defines green hotel as "a hotel that evaluates surrounding ecological condition before starting construction and tries not to aggravate impacts on environment". Therefore, the environment will not be affected while developing tourism industry. To conclude above, a green hotel's goal is to introduce the idea of environmental protection into either hotel hardware or software in order to save energy and reduce wastes. Software in hotel industry refers to the people who provide service and the operational process; the hardware on the other hand refers to the main facilities and constructions.

The core spirit of green hotel aims to reduce environmental impacts and energy consumption while providing products and services to customers. Based on above, we can define a green hotel as a hotel of which managers save water and energy, reduce wastes and environmental impacts through the participation of staff and customers.

The fundamental orientations of a green hotel include: 1. Recycled material 2. Recyclable 3. Low-polluting 4 Energy-saving. A green hotel needs to promote the idea of environmental protection through operating recycling, planning recycle system, and utilizing solar energy, wind energy, biomass energy, hydraulic power. For example, hotels can plant real flowers and plants and provide related ecological travel options for their customers. They should also invest more environmental protection spirit into facilities or services (Lee $\mathrm{Ni}, 2002$ ). According to the Japanese criteria, green hotels should take into account the concept of "green construction" while it is being designed, which means of recycled materials such as aluminum, glass, iron, steel, brick should have priority for being used in construction. Brightness of the building, radiating effect, and waste material disposal should all be taken into account when designing the construction as well.

\subsection{Certification of Green Hotel}

Many countries have started adding ECO-labeling system for green hotel into their ecological plan. For example, United Nations Environment Program sets up an ECO-labeling plan to certify and label qualified hotels (Basel Al-Yousfi, 2006). There are 5 different labels used to certify hotels, waster materials disposal, energy efficiency, hydraulic power management, staff environmental education, environmental guidance, and natural area of protection respectively. They also provide suggestions to those which have successfully obtained qualified labels (Zhang Hong Sheng, 2010). 
Hotel industry makes great impacts on the environment; therefore, certifying hotels for their environmental protection efforts has become a trend. It can help business obtain benefit through abiding by the eco-criteria and give small business opportunities to get a place in the market. Many governments and associations are making efforts on planting the spirit of environmental protection into hotel management, such as Israel's ongoing program of developing criteria for green hotel, United Nations' Green leaf Eco-rating Program (UNESCO), and International Hotel Association's “ The Hotels' Environmental Charter”(Chen Rui Ling, 2000).

The trend of green hotel has been followed for years in other countries. Green Seal in America (Joshi, 2004) has released the guidance of green hotel Canada released Environmental Choice in 1998 with 140 hotels' participation.

\section{Method}

This study is conducted with qualitative study method. Information is acquired through case analysis and interviews with experts. Based on the overviews from hotel senior managers along with literature review, we investigate the related issues of green hotel development. Subsequently, we studied cases of current green hotels in Taiwan and compare them with related theories. Conclusions and suggestions were made in the last part of this study. The examined hotels of this study are the Westin Taipei and the Far Eastern Plaza, which have successfully achieved the goals of green hotel. We selected experienced hotel managers from north, south, and center of Taiwan. Their basic information is listed below:

Table 1. Information of interviewees

\begin{tabular}{|c|c|c|c|}
\hline Interviewees & Manager A & Manager B & Manager $\mathrm{C}$ \\
\hline Location & North & South & East \\
\hline Number of rooms & 500 & 550 & 200 \\
\hline $\begin{array}{l}\text { Number of employees } \\
\text { (including full time and part } \\
\text { time employees, hourly } \\
\text { workers excluded) }\end{array}$ & $\begin{array}{l}\text { About } 562 \\
\text { employees }\end{array}$ & $\begin{array}{l}\text { About } 650 \\
\text { employees }\end{array}$ & $\begin{array}{l}\text { About } 200 \\
\text { employees }\end{array}$ \\
\hline Current position & $\begin{array}{l}\text { General } \\
\text { Manager }\end{array}$ & Manger & $\begin{array}{l}\text { Vice General } \\
\text { Manager }\end{array}$ \\
\hline
\end{tabular}

\section{Case Study}

\subsection{The Westin Taipei}

In order to address the trend of green hotel responses, the Westin Taipei (including all its related business such as Leofoo inn and Leofoo resort in Kenting) carried out the practice of environmental protection. Since $1^{\text {st }}$ January 2008 , the hotel stopped displaying or offering disposable toiletries voluntarily except for soap, shampoo, hair conditioning, and shower gel. Prior to this policy implementation, a three-month educational guidance was conducted inside the hotel by leaving guidance card and message on the desk and toilet in the rooms in order to build the concept of environmental protection into customers' mind. The public relation manger of the marketing department indicated that the execution of environmental protection plan caused a great impact on customers because of customers' stereotyped experience with hotels. She mentioned that most customers, about $80 \%$, were from western countries and did not find it odd about the new measure. However, there were 5 complaint cases filed by local tourists in the first month of the new policy. They received customers' complaints for carrying out environmental protection actions while other hotels were still waiting and observing. The manager of The Westin Taipei suggested that before the concept of green hotel becomes popular, hotels should have toiletry pouches ready for customers. When a guest calls the service desk for it, it should be provided to the guest's room right away. Once customers get used to the new measure, hotel can stop offering disposable toiletries to the guests.

For water saving, the hotel uses water-saving faucet instead of the regular one. Besides, there are notes indicating "no need to clean the bed sheet or the towels" in the room. If a guest is going to stay more than one day, he can leave the note on the bed or the bathroom to let the cleaning ladies know that those things do not need to be changed. It can reduce the number of times of changing sheets and towels as well as reduce the consumption of detergent and sewage disposal. For wise power saving, the hotel uses power-saving bulbs and adopts heat-saving generator, which can recycle the exhausted fume from air conditioner and transfer it to 
heating power for water heater. A lot of energy can be saved through the process of transformation among different types of energy. Other than water and power saving, the classification of waste materials plays a major role in a green hotel as well. The recyclable materials can be divided into paper and magazine, glass bottles, aluminum and iron bottles, and plastic bottles. Provision is also taken that the polluting material such as battery and cartridge is retrieved properly. Other types of garbage can be picked up by the contracted recycling company. In addition, the hotel adopts green laundry bag, soap, and hand gel. Although the consumables are still provided to the hotel guests, the hotel tries to use green products in all staff's facilities and restrooms. Green products such as recycled paper have priority to be selected while purchasing stationary. They also tried to reduce the use of plastic or materials which are difficult to be decomposed.

\subsection{Far Eastern Plaza}

Far Eastern Plaza became the first hotel which passed IS14001 Environmental Management Standard (EMS) in January, 2001. It also got certified by British Lloyd's register in April, 2004. The hotel stipulated and carried out their policies and goals for environmental protection to reduce and recycle waste materials. They place notes inside the guest rooms to remind their guests about energy saving. Related to their achievements, they became the benchmark for environmental protection in the hotel industry. Inside the hotel, the energy system was integrated into monitor system and examined regularly. The adopted technological improvement includes increasing power coefficient to obtain the best power rate, adopting frequency convention control for air conditioning system, power-saving lighting, ultrared lighting, and furnace oxygen concentration monitor. Bi Ri Xing whom is the manager of the Far Eastern Plaza pointed out that the hotel can save 2.78 million KWh every year through monitor system and technological improvement. The total saved cost from energy saving is as high as 5.63 million dollars. Thus, the performance of energy saving is significant. The hotel also sets up an organization for energy saving to improve the task of energy saving.

For water saving, Far Eastern Plaza added water limiter on the faucet, ultrared sensors on the handicapped toilet and man's toilet to avoid urine build up of hard scale, so the flashing works properly and water can be saved. The waste water of the swimming pool can be reserved for fire control. Landscape fountain can be shut down automatically to reduce evapotranspiration when the sensor detects over-speed wind. The engineering department found a way to collect rainwater for the use of water fountains. The air conditioning system consumes great amount of water as well, so they retrieve the steam water produced from large air conditioning box and pumped it into the air conditioning engine. The cost of equipment installation can be retrieved in 5 months.

When promoting the idea of green hotel, the most important thing is to keep interactions with customers. Far Eastern Plaza places cards to promote the green idea in Chinese, English, and Japanese, hoping to appeal to customers for corresponding environmental protection. This is noted on the card that "according to the statistics, the detergent that people use for cleaning towels is polluting our water on earth; thousands of towels are repeatedly being washed. For the earth's sake, we hope you can leave your towels on the rack or on the hook behind your door if you intend to use them again. We will be glad to replace any towels left else where. Thank you for your understanding and making efforts on environmental protection" Mr. Wei said that most guests staying in Far Eastern Plaza are highly educated and can understand the purpose of not changing clean towels is not to save cost for the hotel but to protect our environment. With this measure, guests can decide if they want to change clean towels by themselves and the hotel keeps its quality service. The results shown on the comparison report of occupancy rate and energy consumption were impressive since the occupancy rate was increased while water consumption is reduced (Table 2). 
Table 2. Far Eastern Plaza's action and outcome of environmental protection

\begin{tabular}{|c|c|c|}
\hline Goals & Actual Action & Outcome \\
\hline Energy saving & $\begin{array}{l}\text { 1. Add water limiter on the faucets in the hotel rooms } \\
\text { 2. Install ultrared sensor on the faucets in staff's restrooms. } \\
\text { 3. Use water-saving toilet in public areas and staff's restrooms. } \\
\text { 4. Recycle rainwater, steam water from air conditioner, and } \\
\text { swimming pool water for the use of cooling tower. } \\
\text { 5. Reinforce guidance, ex. place notes to appeal long stay guests } \\
\text { not to change clean towels when it's not necessary. } \\
\text { 6. Place water saving slogan in the staff's restrooms. }\end{array}$ & $\begin{array}{l}\text { Awarded by Water } \\
\text { Resources Agency for } \\
\text { the water saving group } \\
\text { competition. }\end{array}$ \\
\hline $\begin{array}{l}\text { Policy of } \\
\text { environmental } \\
\text { management }\end{array}$ & $\begin{array}{l}\text { 1. Stipulate policies and goals of environmental protection } \\
\text { 2. Examine the practice and drills of environmental protection } \\
\text { periodically. } \\
\text { 3. Staff should abide by the green principles, reduce energy } \\
\text { consumption, and recycle materials. } \\
\text { 4. Place notes in the hotel rooms to remind guests of energy } \\
\text { saving } \\
\text { 5. Foster the woods area in bamboo lake of Yanminshan and } \\
\text { continuously plant trees and mow the weeds. } \\
6 \text {. Twice a year hold a volunteer activity to clean the beach. }\end{array}$ & $\begin{array}{l}\text { Certified by Taipei } \\
\text { Development Bureau as } \\
\text { "group of making great } \\
\text { efforts on keeping } \\
\text { forests" }\end{array}$ \\
\hline
\end{tabular}

(Data collected by author, 2010)

\section{Interviews with Senior Managers}

After fully understanding the concept and management of green hotels in local hotel industry, we will further discuss and analyze how to build and manage a green hotel based on five aspects based on the interviews with the senior managers.

\subsection{Green Purchase}

Chai Song Lin (2001) suggested that purchase is like voting, which is the greatest power to protect our environment and human existence. Therefore, he proposed the principle of 3R3E which includes reduce, reuse, recycle, economic, ecological, and equitable. Some scholars believe that purchase policy is the key of a hotel's environmental protection measure, so the management of supply chain is very important to a hotel (Seuring, 2001). In order to find suitable suppliers which can meet hotel's polices of environmental protection, hotels should cooperate with suppliers which have clear policy of environmental protection as well. It would be useless if a hotel's suppliers or vendors can not keep up with the hotel's green policy. Cunha (2002) also suggested that a hotel should work with its suppliers and try to develop energy saving products. Through working tightly with suppliers, the business can improve their own products.

The challenges that managers might face is that they are not sure if the variety of products can satisfy customers' needs and if customers will to accept reused and recycled products before making purchase decision. Price of such purchases will be relatively higher and it will be more difficult with fewer options of products and suppliers. However, such policies can make best use of energy, reduce pollution, and reduce cost. Moreover, it can keep customers and staff in good health and business reputation can be built through it as well.

\subsection{Environmental Policy}

During the interviews, we learnt that policies are difficult to carry out if hotel managers do not understand the policy, or the staff, customers, and suppliers are not able to execute the plan properly. Therefore, hotel managers think that stipulating green policy is an easier task, but government's guidance, reward system, and consultation is much more important for promoting the idea of environmental protection. The problem is that current laws and policies cannot be carried out properly. Environmental policy stipulation, water and energy saving, software and hardware, and equipment and technology, all need to be supported by the government. In addition, the government needs to build up a management standard and related certificate of green hotel. Some managers also suggested that environmental protection measure might cost a lot of money, so it is difficult to persuade hotel 
owners to implement green policy while they are facing financial difficulties or slow market. They might think such strategy would increase hotel's operation cost or even affect hotel's financial situation because they do not understand how much benefit they might get through implementing green policy. Therefore, it is suggested that government should allot funds or exempt taxes to encourage hotels to set up related hardware (for water-saving and energy-saving) and improve software such as improving service procedure or adding the idea of environmental protection into training courses. It can reduce hotel managers' doubts about implementing green policies.

\subsection{Hotel Management}

Green labeling system and hotel staff's professional knowledge are both important keys for green policy execution. Though, this type of change might cause extra cost which includes visible and invisible cost such as development cost. Hotel managers indicate that our perception needs to be adjusted and suitable management criteria need to be set up. Everybody needs to know what his responsibility is and updated record should be kept all the time. All of these are not easy and need to be done by entire employees' efforts. Nevertheless, most managers consider this aspect as the easier one, although management system and the outcome might be diversified among different hotels. Hotels need to make efforts on staff's professional training, employees' recognition, and cooperation. If all the above can be properly executed, managed, and monitored, the quality of the entire environment will be enhanced significantly. Not only can hotels get customers' approval for their service quality, but its competiveness will be increased as well.

\subsection{Employees Education}

Employees' personal behaviors need to be changed when a hotel is trying to promote green measures and increase its efficiency. Hotels need to train, teach, and offer rewards to employees who provide useful comments on environmental improvement. Hotels also need to make their employees fully understand why they implement the green policy, and what they can do to reduce energy consumption and reduce environmental pollution through personal behaviors. Training employees, making them get used to it, and then understand, cooperate, carry out, and achieve the goals are all challenges hotels might encounter. When conducting training, hotels' managers need to consider the possibility of its proper conduct and the potential of employees cooperation after the training implementation. The goal of employee training is to reduce impacts on environment and energy consumption in the business life cycle. Training can also maintain service quality to meet customers' needs and attract more customers who have better idea about environmental protection. Inside the hotel, training can increase employees' approvals toward the company, which means not only can green policy enhance employees' behaviors to protect the environment, but it can continuously advance the business to the goal of an excellent environment. Whenever hotels make their employees fully execute the green plan, we believe it can increase the entire management efficiency as well as increase the entire employees' quality. In addition, training can make employees fully understand the concept of environmental protection, so that they might carry out the idea in both work and living environment.

\subsection{Consumer Education}

Consumers must recognize the fact that environmental protection is to keep the last piece of clean land for our future generations. Therefore, selecting green hotel is the only choice and the government should try harder to promote the idea of environmental protection, so people's willingness of selecting green hotels will be increased. Not only can it remain our living environment and living quality, it would also make hotels speed up to transform to green hotels through consumers' power. Hotel managers indicated that other than consumers' cooperation, the effectiveness of environmental protection guidance also depends on the customers' acceptance and perception. For example, customers might think recycling is not handy and bothersome. For sure, room rate is the major concern for customers, but with the same price rate, customers can easily recognize the hotel's effort and gain more knowledge about green hotel. Therefore, they might come back again next time. Besides, hotels can place brochures or notes of environmental protection inside the room in case customers are not aware of hotels' efforts on environmental protection. However, hotel managers must remember they should not ask customers to take the full responsibility without getting any benefit. For example, hotels can share the benefit with customers who follow hotels' green measure. For example, when customers agree to not change clean towels, hotels can provide a certain amount of discount to them.

In conclusion, hotels can save operational cost and reduce the entire societal cost through carrying out green management. In addition, it can also increase hotels reputation and popularity, and brand effect, all forming invisible assets that the hotels can gain. Meanwhile, through self-examination, hotels can reach the standard of green hotel and strengthen its key competitiveness towards the environmental protection and highlights of 
hotels' features.

\section{Conclusion}

We concluded that many hotels have benefited from green management such as enhanced reputation and more quality customers. For the business reputation, it reduces business's cost for posting advertisements and the clear hotel's orientation shows hotels' positive image, which might increase employees' identification toward the business. In parallel, the green marketing is effective. When consumers have positive perception, concept, and recognition towards green hotel, they can be attracted by the green hotel concept and participate in environmental protection themselves. It is very beneficial that a hotel would be able to provide a better environment while enhancing customers' educational level at the same time.

In fact, no matter in Taiwan or other countries, the concept of green hotel has become an irreversible trend and it will become one of the key indexes for anti-green house effect in the near future. Travel is an important part for people in the modern society, so choosing a green hotel to stay might be the best way to connect consumers and environmental protection. The major challenge is that we do not know if consumers can accept and cooperate with hotels' green measures since it is highly potential them to be opposed with this idea of environmental protection. If they shoe content with the hotels' green concept, the result of the measure will be very significant. Managers indicated that not only does green hotel attract highly educated consumers; it can also save energy through educating consumers, improving hotel and the whole society's environment. Overall hotels, through the mass media service, hotels will gain good impact for making efforts on environmental protection.

\section{References}

Basel Al-Yousfi. (2006). ECO-Labling- THE CONCEPT \& IMPLICATIONS. Regional Workshop on Trade and Environment Capacity Building. Muscat, Sultanate of Oman. Retrieved from http://css.escwa.org.lb/25mar06/4.pdf

Bohdanowicz, P., \& Martinac, I. (2007). Determinants and benchmarking of resource consumption in hotels - Case study of Hilton International and Scandic in Europe. Energy \& Buildings, 39(1), 82-95. http://dx.doi.org/10.1016/j.enbuild.2006.05.005

Chen Rui Ling. (2000). Green Building Rating and Labeling System. International Conference Dissertation of Sustainable Building Environment in the 21st century. Ministry of the Interior Building Research Institute.

Cunha Lemos, A. D., \& Giacomucci, A. (2002). Green procurement activities: some environmental indicators and practical actions taken by industry and tourism. Environment and Sustainable Development, 1(1), 59-72. http://dx.doi.org/10.1504/IJESD.2002.000718

Erdogan, N., \& Baris, E. (2007). Environmental protection programs and conservation practices of hotels in Ankara, Turkey. Tourism Management, 28, 604-614. http://dx.doi.org/10.1016/j.tourman.2006.07.003

Green Hotels Association. (2007). What Are Green Hotels. Retrieved from http://www.greenhotels.com/whatare.htm

Green Hotels in the Green Mountain State. (2006). What Is A Green Hotel. Retrieved from http://www.vtgreenhotels.org/whatis.htm

Joshi, Manoj. (2004). Are Eco-Labels Consistent with World Trade Organization Agreements? Journal of World Trade, 38(1), 69-92.

Judy, L., Holcomb, Randall, S., Upchurch \& Fevzi Okumus. (2007). Corporate social responsibility: what are top hotel companies reporting? International Journal of Contemporary Hospitality Management, 19(6), 461 - 475. http://dx.doi.org/10.1108/09596110710775129

Kong Fang Zheng, Xu Hong Zhe, Huang Hui Fen \& Fu Yan Jing (2001). Environmental Management System in the Hotel Industry - Case of Consumers' Acceptance in Taipei Area. Outdoor recreation quarterly journal, 14 (4), 1-26.

Lee Ni. (2002). Green Leaves label for Green Hotel. China Airlines Journal, May, 20-22.

Liao, Tzu-Hsuan \& Su, Wen-Yu. (2007). The Research of the Attitude, Behavior and Pleasure of The B \& B Possessor in Taiwan. Retrieved from http://ndltd.ncl.edu.tw/cgi-bin/gs32/gsweb.cgi?o=dnclcdr\&s=id=\%22094PCCU0571001\%22.\&searchmode=b asic

Mountain State. (2006). Green Hotels in Green Mountain State, What is A Green Hotel? Retrieved from http://www.vtgreenhotel.org/whatis.htm 
Seuring, S. A. (2001). Green Supply Chain Costing. Greener Management International, 33, 71.

Shen Jia Wei \& Wan Jin Sheng. (2001). The Conception and Analysis of Tourist Green Hotel Managers in Taiwan Area. Study of Tourism Management, 1(1), 71-86.

Tourism Council Australia Aviation Policy. (1998). Tourism Council, March, 1998.

Ye Bi Hua, Cai Jin Fa \& Huang Zong Cheng. (2003). The Relation between Consumer Behavior toward Environmental Protection and their Hotel Preference. Study of Environment and Management, 4(2), 61-81.

Zhang Hong Sheng \& Liu Zhi Ling (2010). A study of Green Marketing and Environmental Protection Label in Taiwan Hotel Industry. Health Management Journal, 8(1), 47-60. 